Research Article

\title{
Calculation Approach for Lateral Bearing Capacity of Single Precast Concrete Piles with Improved Soil Surrounds
}

\author{
Guangyin Du, ${ }^{1}$ Anhui Wang, ${ }^{1}$ Liye $\mathrm{Li}^{,}{ }^{2}$ and Dingwen Zhang $\mathbb{D}^{1}$ \\ ${ }^{1}$ School of Transportation, Southeast University, Nanjing, Jiangsu 210096, China \\ ${ }^{2}$ Tianjin Municipal Engineering Design \& Research Institute, Tianjin 300392, China \\ Correspondence should be addressed to Dingwen Zhang; zhangdw@seu.edu.cn
}

Received 11 January 2018; Revised 21 May 2018; Accepted 13 June 2018; Published 12 July 2018

Academic Editor: Li Li

Copyright ( 2018 Guangyin Du et al. This is an open access article distributed under the Creative Commons Attribution License, which permits unrestricted use, distribution, and reproduction in any medium, provided the original work is properly cited.

Precast concrete (PC) piles with cement-improved soil surrounds have been widely used for soft ground improvement. However, very few calculation approaches have been proposed to predict the lateral bearing capacity. This study aims at investigating the lateral capacity of a single PC pile reinforced with cement-improved soil through a series of 3D finite element analyses and theoretical studies. It is revealed that application of cement-improved soil around the PC pile can obviously reduce the induced lateral deflections and bending moments in the pile and can significantly increase its capacity to resist lateral loading. To account for the reinforcement effect of cement-treated soil, a modified $m$ approach is proposed by introducing a modified coefficient to enable the predictions of the lateral bearing capacity for such reinforced PC piles. It is revealed that the modified coefficient is approximately linearly related to the compressive bearing capacity of improved soil surrounds.

\section{Introduction}

Deep cement-mixing (DCM) column has many advantages, such as a large volume, limited environmental disturbance, rapid construction, and low cost, so it is extensively used in soft ground improvement. However, the DCM column strength is significantly affected by soil conditions, which results in a low column uniformity and poor reinforcement effect [1]. Although a precast concrete (PC) pile has many advantages with various applications, the strength of the concrete pile cannot be sufficiently utilized under either vertical or lateral loading, and failure caused by soil failure can always occur, which makes it uneconomical for use in soft ground improvement [2]. To solve the abovementioned problems, the PC pile with improved soil surrounds, produced by inserting a PC pile into a DCM column before the initial setting of cement-improved soil (Figure 1), has recently been proposed $[1,2]$. In this way, the high-strength PC pile is designed to bear a load, and the improved soil surrounds act to transfer axial force into the surrounding soils by skin frictions [2]. To date, this new type of composite pile has attracted considerable attention owing to its low cost and high effectiveness and has been successfully applied to soft ground improvement [3-5].

To investigate the vertical bearing characteristics of PC piles with improved soil surrounds, a series of pile load tests, numerical simulations, and theoretical models have been carried out [5-9]. These studies verified that the application of cement-improved soil surrounds could greatly improve the vertical bearing capacity of the PC pile and reduce its settlement. However, further studies are also needed to evaluate the contribution of improved soil surrounds to the lateral performance of PC piles. Liu [10] performed full-scale lateral load tests on several PC piles with improved soil surrounds. The test results showed that owing to the presence of outer improved soil surrounds, the lateral bearing capacity and the lateral stiffness of the PC piles are significantly increased. Rollins et al. [11] performed lateral loading tests on an existing pile group modified with jet-grouting and cementmixing column reinforcement around the pile caps. It was observed that the lateral resistance of the existing pile group foundations could be significantly increased with jetgrouting and cement-mixing reinforcement. Based on the field tests of Rollins et al. [11], Lin et al. [12] used the finite 


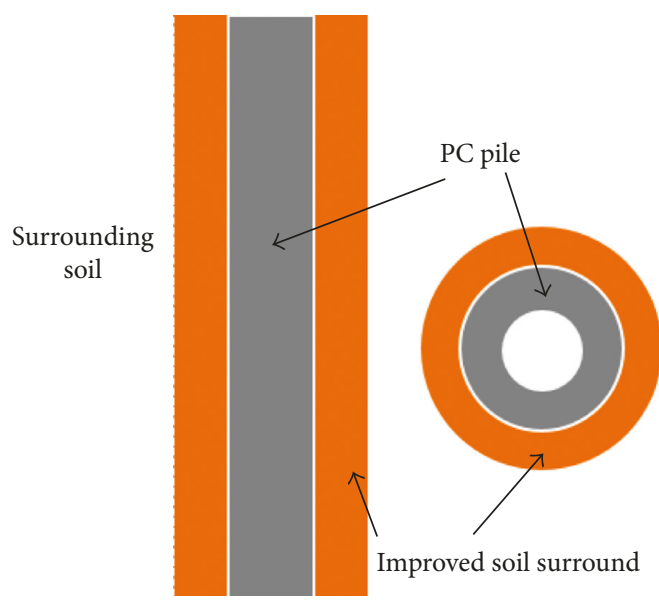

(a)

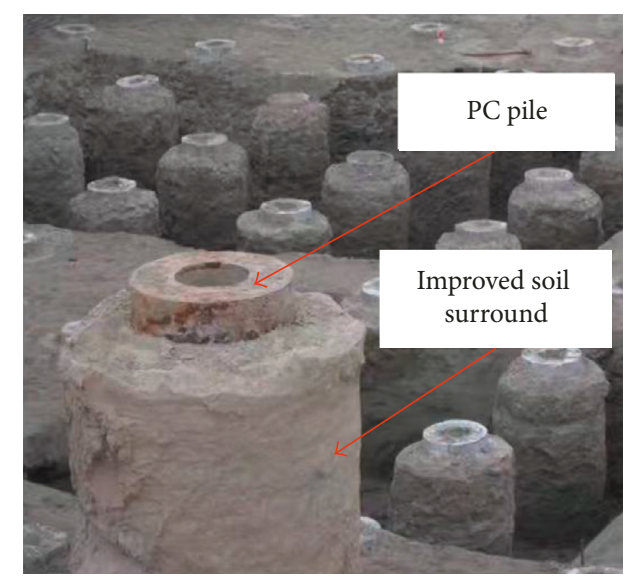

(b)

Figure 1: (a) Schematic diagram of PC pile with improved soil surround; (b) photo of field excavation.

difference simulation method to model the laterally loaded pile groups in soft clay with or without the jet-grouting columns. In addition, Wang et al. [13] and He et al. [14] carried out monotonic and cyclic lateral loading tests to investigate the contributions of the jet-grouting column reinforcement to improve the lateral performance of the single cast-in-place pile.

Although field observations and numerical modeling of laterally loaded piles with jet-grouting or cement-mixing column reinforcement have been reported, systematic studies pertaining to the contributions of cement-treated soil surrounds to the lateral capacity of PC piles are still somewhat lacking. Indeed, there is still much that is not well understood about the lateral capacity of PC piles with such improved soil surrounds. In addition, there has generally been a limited amount of theoretical studies pertaining to the lateral bearing capacity of single PC piles with improved soil surrounds, so this requires further investigation.

This paper aims at conducting a comprehensive study on the lateral response of PC piles with improved soil surrounds as well as the $m$ approach for predicting the bearing capacity under lateral loading. To achieve the research objectives, three-dimensional (3D) numerical analyses that were first validated against field test results were performed using Midas/GTS finite element software. The effect of outer improved soil surrounds on the lateral response of PC piles was further assessed. Moreover, a modified $m$ approach accounting for the cement-improved soil reinforcement was proposed for the reinforced piles within the cohesive soil, and the suitability of the proposed $m$ approach for predicting the lateral bearing capacity of such reinforced piles was also assessed.

\section{Numerical Simulations}

In order to evaluate the effect of cement-improved soil surrounds on the lateral bearing performance of a PC pile, the Midas/GTS software was used to establish threedimensional models of PC piles with and without improved soil surrounds under lateral loading, according to the full-scale pile load tests. The test project was performed in Nantong, which is located along the southeast coast of China. Extensive field tests and laboratory tests were performed to characterize the subsoil conditions. Specifically, conventional laboratory soil tests were carried out to determine the unit weight, compression modulus, and relevant shear parameters of the soil mass. Moreover, a cone penetration test (CPT), which is one of the most commonly used field test approaches in geotechnical investigations, was performed to determine the ultimate unit skin friction and tip resistance. The soil profile and engineering properties of the test site are presented in Figure 2. It can be seen that the soil profile near the ground surface consists of a marine silty clay layer underlain by a silty sand deposit. The deflection and bending moment distribution of the two types of piles are then investigated in detail. The detailed information of the test piles is shown in Table 1.

2.1. Numerical Modeling. In general, there are different numerical approaches for analysis of the lateral bearing capacity of a single pile [15]. One approach is to establish the pile-soil model based on the lateral pile-soil interaction. The other is to establish the pile-spring model by replacing the pile-surrounding soil with equivalent spring and damping based on the Winkler elastic foundation beam theory. Although the pile-spring model can simulate the compressive and nontensile behavior of pile-surrounding soil, it cannot reflect the plasticity of pile-surrounding soil. It is well known that with a gradual increase in the lateral load applied at the pile head, the pile-surrounding soil changes from behaving elastically to plastically, and the plastic zone around the pile is gradually extended. In addition, in the pile-spring model, the size of the pile-soil contact surface is assumed to be constant under different loading conditions. In the pile-soil model, however, the contact surface may change with varying loading conditions, which is more consistent with the actual pile-soil interaction. Therefore, the pile-soil model was adopted in this study. 


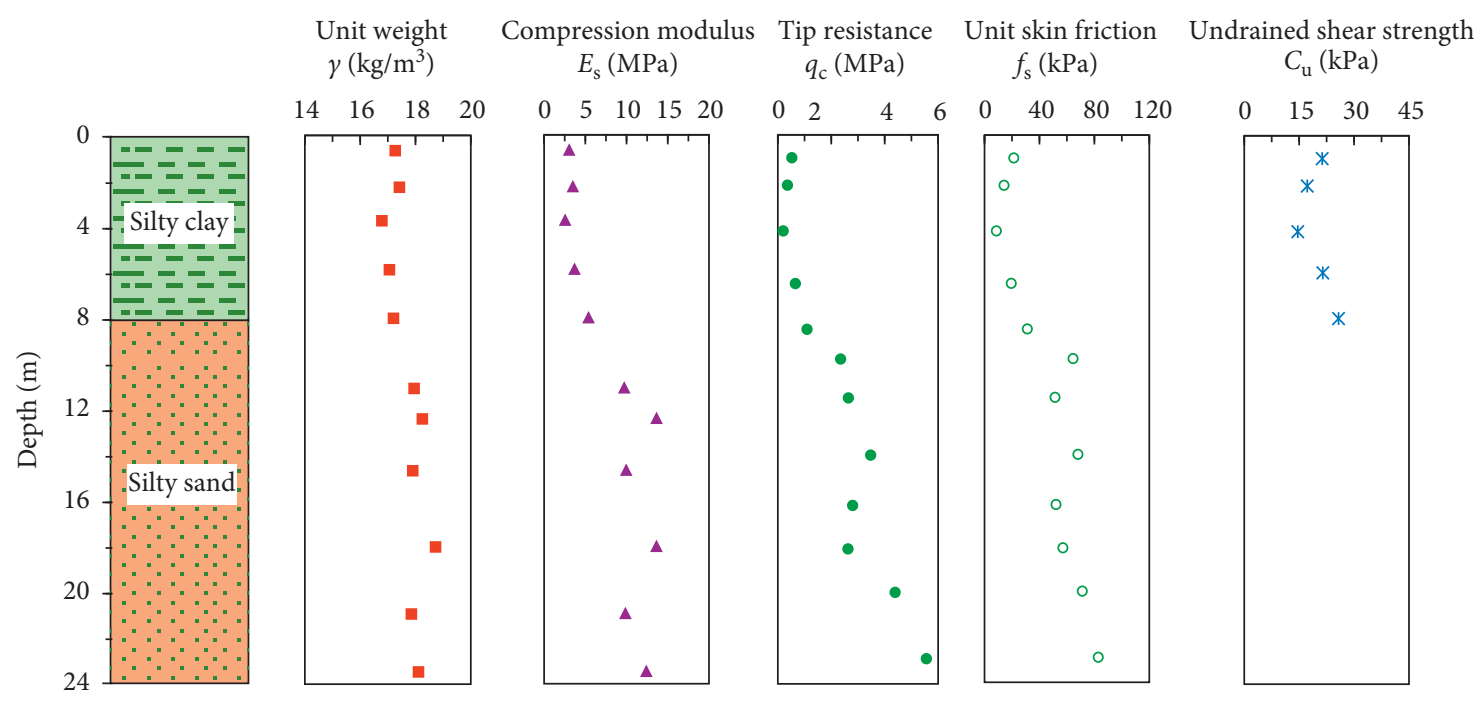

FIgURE 2: Soil profile and engineering properties of the test site.

TABle 1: Detailed information about test piles (PCI-1 and PC-1).

\begin{tabular}{|c|c|c|c|c|c|c|}
\hline \multirow{2}{*}{ Pile identifier } & \multirow{2}{*}{ Concrete grade } & \multicolumn{3}{|c|}{ PC piles } & \multicolumn{2}{|c|}{ Improved soil surrounds } \\
\hline & & Outer diameter $(\mathrm{mm})$ & Wall thickness (mm) & Length (m) & Outer diameter $(\mathrm{mm})$ & Length $(\mathrm{m})$ \\
\hline PCI-1 & $\mathrm{C} 80$ & 400 & 95 & 12 & 800 & 12 \\
\hline PC-1 & $\mathrm{C} 80$ & 400 & 95 & 12 & - & - \\
\hline
\end{tabular}

Note. PCI $=$ PC pile with improved soil surround; PC = PC pile without improved soil surround.

The typical 3D finite element models used for the analyses are shown in Figures 3(a) and 3(b). In the horizontal direction, the surrounding soil was extended by 10 times greater than the pile diameter. Meanwhile, in the vertical direction, the surrounding soil was the same length as the pile. The soil and pile were modeled using 3D eight-node linear brick elements, with a refined mesh of 33,600 elements. Particularly, the mesh used for the soil was sufficiently fine in the region close to the pile. Regarding the meshing convergence issue, a numerical test shows that further halving the current mesh size can only result in a change of numerical results of no more than $0.6 \%$. This suggests that sufficiently accurate simulation results can be achieved with the mesh size adopted in this study.

A total stress analysis under undrained conditions was adopted in this study to simulate the field lateral load tests on the PC pile with improved soil surround, which did not account for the pore water pressure response. Such a modeling technique has been used by many scholars [16-20] in investigations of the behavior of a single pile subjected to lateral loading. Accordingly, the total stress parameters for both the undrained modulus and shear strength of the cement-treated and untreated soil were assigned in this numerical study. The Mohr-Coulomb failure criterion was adopted to compute the failure loads of pile-surrounding soils deforming under undrained conditions. The undrained shear strength $C_{\mathrm{u}}=20 \mathrm{kPa}$ and undrained Young's modulus $E_{\mathrm{u}}=750 C_{\mathrm{u}}$ for the silty clay were then determined through the undrained shear tests and the work of $\mathrm{He}$ et al. [20], respectively. The cement-treated soil was also assumed to obey the Mohr-Coulomb failure criterion. Specifically, the undrained shear strength and Young's modulus of the cement-treated soil were obtained from the work of Jamsawang et al. [21] and Tyagi et al. [22]. According to Jamsawang et al. [23], the tensile strength $\left(\sigma_{t}\right)$ of cementtreated soil can be defined as 0.15 times the compressive strength. The constitutive models and parameters used in this study are listed in Table 2. It is worth noting that the cement-improved soil is considered as homogeneous without varying with depth.

The interaction between the PC pile and the improved soil surrounds was modeled by defining zero-thickness interface bond-slip elements at their contact surfaces, so as to allow for the relative shear displacement between, and the separation of the two objects. The interface cohesion and friction coefficient between the pile and cementtreated soil were derived as $200 \mathrm{kPa}$ and 0.65 , respectively. Considering that slippage and gapping occurs during lateral loading, the interaction between the cement-improved soil and the surrounding soil was modeled using the Coulomb friction model. An interface friction coefficient of 0.35 was applied in this study. The finite element analyses were comprised of two primary steps. First, the initial stress field of the pile-soil system was balanced. In the next step, lateral loads were applied at the pile head by multiple-step loading.

2.2. Validation and Results. Figure 4 compares the measured and computed lateral load $(P)$ versus the deflection $\left(Y_{0}\right)$ curve at the head of the piles with and without improved soil 


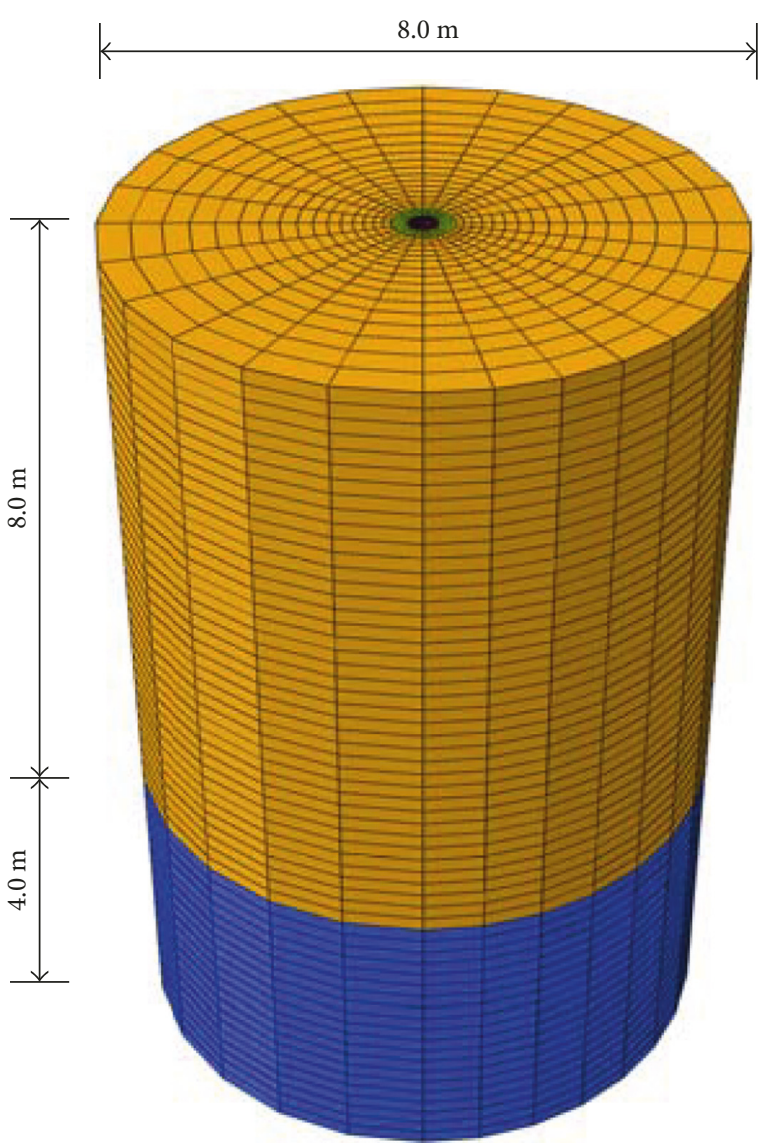

(a)

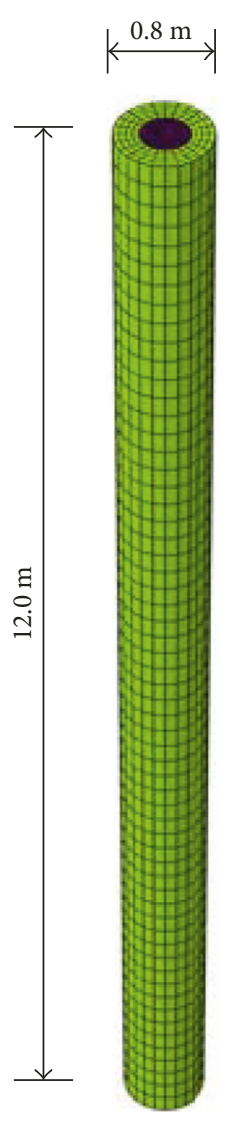

(b)

Figure 3: 3D finite element models of (a) entire pile-soil system and (b) pile with improved soil surround.

TABLE 2: Material models and parameters used in this study.

\begin{tabular}{lccccccc}
\hline Material type & Model & $\gamma\left(\mathrm{kg} / \mathrm{m}^{3}\right)$ & $E_{\mathrm{u}}(\mathrm{MPa})$ & $v$ & $C_{\mathrm{u}}(\mathrm{kPa})$ & $\Phi\left(^{\circ}\right)$ & $\sigma_{\mathrm{t}}(\mathrm{kPa})$ \\
\hline Shallow silty clay & Mohr-Coulomb & 1780 & 15 & 0.49 & 20 & - \\
Deep silty sand & Mohr-Coulomb & 1920 & 35 & 0.49 & - & 30 \\
Cement-improved soil & Mohr-Coulomb & 2100 & 300 & 0.49 & 450 & - \\
PC pile & Linear elastic & 2400 & 38000 & 0.20 & - & - \\
\hline
\end{tabular}

surrounds, respectively. It can be seen that the computed pile-head deflections agreed well with the numerical results in the case of a lateral load less than $100 \mathrm{kN}$. However, when the lateral load exceeded $100 \mathrm{kN}$, the computed results were significantly different from the corresponding measured values. For laterally loaded flexible piles, failure of the pilesoil system can always be a result of the plastic damage of the pile following yielding of the pile-surrounding soil [20,24]. Additionally, the lateral bearing capacities of these two types of piles were determined to be $125 \mathrm{kN}$ and $95 \mathrm{kN}$, respectively, according to Technical Code for Building Pile Foundations [25]. Therefore, in this study, once the lateral load was applied up to $100 \mathrm{kN}$, the severe tension-induced damage in the pile occurred and its flexural rigidity obviously decreased, resulting in a steep increase in the pile deflection. However, the numerical modeling does not take the pile damage into account, which leads to the foregoing difference. It is worth mentioning that the lateral bearing capacity of the PC pile with cement-treated soil reinforcement was approximately $30 \%$ larger than that of the unreinforced PC pile, which indicates an essential strengthening effect with the application of cement-improved soil around a PC pile.

Figure 5 shows the computed lateral deflection along the PC pile with and without improved soil surrounds in the case of a lateral load of $100 \mathrm{kN}$. It can be observed that both types of piles behaved as flexible piles, and the pile deflection decreased nonlinearly from the pile head, with the deflection primarily distributed at the upper part of the pile body. This suggests that the shallow soil layer, which ranged from $0 \mathrm{~m}$ to approximately $5 \mathrm{~m}$ below the ground surface, played a key role in the bearing performance of the PC pile subjected to lateral loading. A comparison indicates that the lateral deflection along the PC pile with improved soil surrounds was obviously smaller than that of the PC pile alone in the soil. This is because the pile deflection at a certain depth was closely related to the pile-soil modulus ratio. When a PC pile 


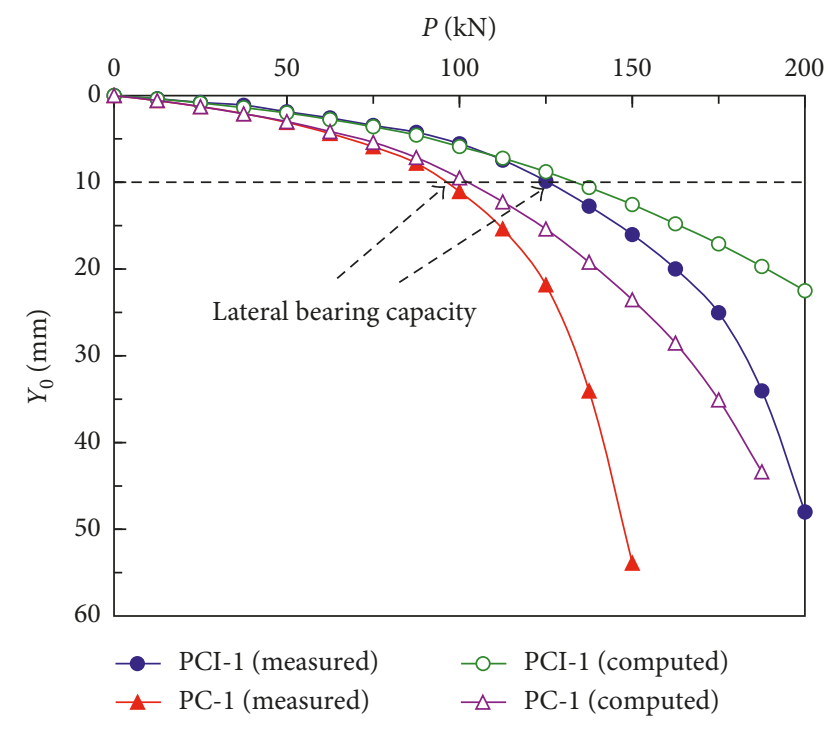

FIgURE 4: Comparisons between the measured and computed $P-Y_{0}$ curves for pile PCI- 1 and pile PC-1.

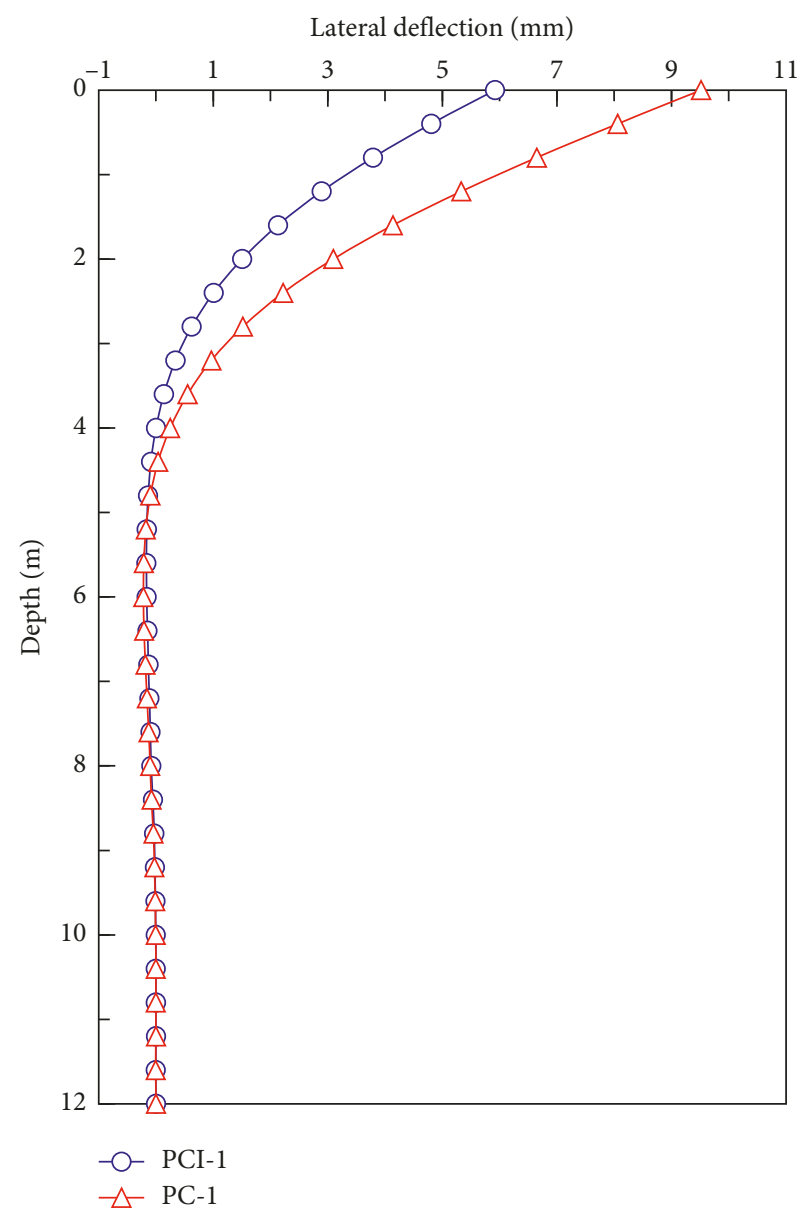

Figure 5: Computed lateral deflection along pile PCI-1 and pile PC-1 at a lateral load of $100 \mathrm{kN}$.

was concentrically inserted into the cement-improved soil surrounds, the greater constraint effect provided by the outer cement-improved soil undoubtedly caused a noticeable decrease in pile deflection.

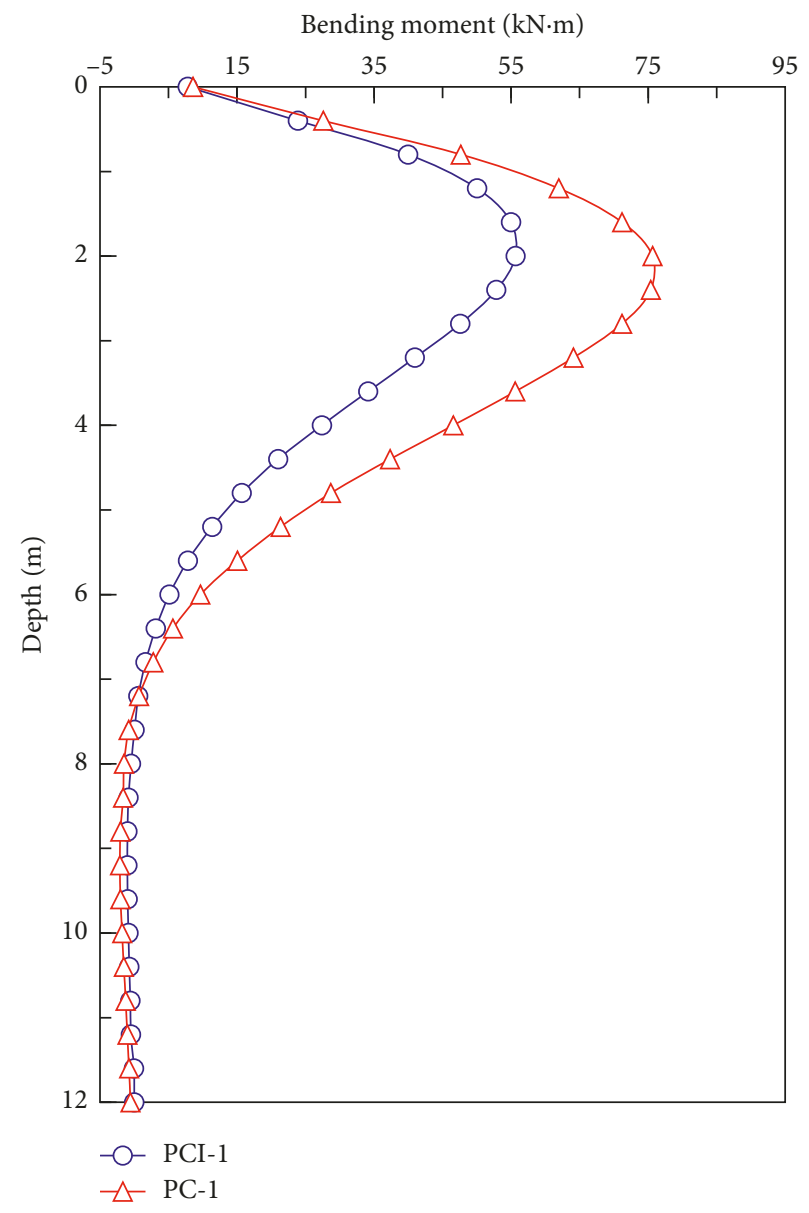

FIgure 6: Computed bending moment along pile PCI-1 and pile PC-1 at a lateral load of $100 \mathrm{kN}$.

Figure 6 shows the computed bending moment along the PC piles with and without improved soil surrounds in the case of a lateral load of $100 \mathrm{kN}$. It is evident that the variations in the bending moment along the PC pile with improved soil surrounds were consistent with that along the PC pile alone in soil. To be specific, the bending moment increased monotonically to a peak and then gradually decreased, which had also been reported by Liu [10]. It is clearly observed that the maximum bending moment of the PC pile with improved soil surrounds was significantly smaller than that of the PC pile alone in soil. This can be attributed to the fact that the presence of the improved soil surrounds resulted in a large equivalent diameter of the pile, which could generate greater soil resistance to the pile deflection, thus significantly reducing the bending moment in the PC pile. The reduction is also in agreement with Voottipruex et al. [6] and Liu [10], who found that the outer improved soil surrounds may play a critical role in load transfer and can effectively transfer the lateral load from the PC pile to the surrounding soil.

Although the application of cement-improved soil around a PC pile could greatly reduce the accumulation of pile deflection and bending moment, both types of piles experienced similar trends when subjected to lateral 
TABLe 3: Value of proportional coefficient $m$ of soil lateral resistance coefficient (JGJ 94-2008).

\begin{tabular}{lcc}
\hline Type of foundation soil & $m\left(\mathrm{kN} / \mathrm{m}^{4}\right)$ & $\begin{array}{c}\text { PC piles } \\
\text { Corresponding lateral deflection of a } \\
\text { single pile at ground surface }(\mathrm{mm})\end{array}$ \\
\hline Muck and muddy soil, saturated collapsible loess & $2000 \sim 4500$ \\
\hline $\begin{array}{l}\text { Liquefied plastic }\left(I_{\mathrm{L}}>1\right) \text {, soft plastic }\left(0.75<I_{\mathrm{L}} \leq 1\right) \\
\text { clayey soil, } e>0.9 \text { silty soil, loose silty fine sand, loose } \\
\text { and slightly dense fill }\end{array}$ & $4500 \sim 6000$ & 10 \\
\hline $\begin{array}{l}\text { Plastic }\left(0.25<I_{\mathrm{L}} \leq 0.75\right) \text { clayey soil, } e=0.75 \sim 0.9 \text { silty } \\
\text { soil, collapsible loess, medium dense fill, slightly } \\
\text { dense fine sand }\end{array}$ & $6000 \sim 10000$ \\
$\begin{array}{l}\text { Hard plastic }\left(0<I_{\mathrm{L}} \leq 0.25\right) \text { and hard }\left(I_{\mathrm{L}} \leq 0\right) \text { clayey } \\
\text { soil, collapsible loess, } e<0.75 \text { dense silty soil, medium } \\
\text { dense medium sand, dense old fill }\end{array}$ & $10000 \sim 22000$ & 10 \\
\hline
\end{tabular}

loading. This suggests that the lateral bearing behavior of the PC pile with improved soil surrounds was similar to that of the PC pile alone in soil. Therefore, the $m$ approach applicable to a single PC pile without improved soil surrounds can still be used to calculate the lateral bearing capacity of a single PC pile with improved soil surrounds. But related parameters in the existing $m$ approach need to be modified so as to reflect the reinforcement effect of improved soil surrounds on the lateral bearing performance of PC piles.

\section{Modified $m$ Approach for PC Piles with Improved Soil Surrounds}

3.1. $m$ Approach. The $m$ approach was proposed based on the Winkler elastic foundation model and Euler-Bernoulli beam theory, and it is assumed that the lateral soil resistance at a certain depth equals the product of the corresponding lateral resistance coefficient and pile deflection. Moreover, the lateral resistance coefficient linearly increases with the depth and is equal to zero at the ground surface.

According to the Technical Code for Building Pile Foundations [25], the calculation formula for the lateral bearing capacity of a single PC pile is expressed as

$$
R_{\mathrm{ha}}=\beta \frac{\alpha^{3} \mathrm{EI}}{v_{\mathrm{x}}} \chi_{0 \mathrm{a}},
$$

where $R_{\mathrm{ha}}=$ design value of the lateral bearing capacity of single PC piles $(\mathrm{kN}) ; \beta=$ reduction coefficient, generally taken as 1.0; $\chi_{0 \mathrm{a}}=$ allowable lateral deflection at pile head $(\mathrm{m}) ; v_{\mathrm{x}}=$ pile-head deflection coefficient; EI = flexural stiffness of pile $\left(\mathrm{kN} \cdot \mathrm{m}^{2}\right)$; and $\alpha=$ lateral deformation coefficient of pile, which is given as

$$
\alpha=\sqrt[5]{\frac{m b_{1}}{\mathrm{EI}}},
$$

where $b_{1}=$ calculation width of pile $(\mathrm{m})$ and $m=$ proportional coefficient of lateral resistance coefficient $\left(\mathrm{kN} / \mathrm{m}^{4}\right)$, which can be determined by the Technical Code for Building Pile Foundations [25], as summarized in Table 3.

It should be noted that for the PC piles with improved soil surrounds, the flexural stiffness and tensile strength of the outer cement-improved soil are significantly lower than that of the inner PC pile, and severe cracking in cementimproved soil can be easily induced under lateral loading. In other words, slippage and separation is likely to occur at the interface of the PC pile and the cement-improved soil during loading. Thus, the two parts of the reinforced piles cannot work together to support and transfer the lateral load effectively, especially in cases of cement-improved soil with low strength. Based on the above analysis, it is reasonable to treat the outer improved soil surrounds as the pilesurrounding soil with greater soil resistance, rather than as the extended diameter of a PC pile. As a result, the parameters EI and $b_{1}$ of the PC pile were used to predict the lateral bearing capacity of a PC pile with improved soil surrounds.

It is well known that the proportional coefficient, $m$, is a key parameter for analysis of laterally loaded piles when using the $m$ approach. However, the $m$ value is closely dependent on soil properties, pile material, loading conditions, and so on [26]. Hence, in order to determine the $m$ value applicable to PC piles with improved soil surrounds, it is required to consider the reinforcement effect of improved soil surrounds on the lateral PC pile.

3.2. Back-Calculation of $m$ Value. In cases of the lateral load on the free-head pile is applied at the ground surface, the coefficient, $m$, is determined from (1) and (2) as follows:

$$
m=\frac{\left(v_{\mathrm{x}} P\right)^{5 / 3}}{b_{1} Y_{0}^{5 / 3}(\mathrm{EI})^{2 / 3}}
$$

where $P$ and $Y_{0}=$ lateral load $(\mathrm{kN})$ and pile-head deflection (m), corresponding to $R_{\mathrm{ha}}$ and $\chi_{0 \mathrm{a}}$, respectively.

From (3), it can be seen that the variation of $m$ with $Y_{0}$ can be deduced according to the $P-Y_{0}$ curve derived from pile load tests. In general, at a pile-head deflection of $10 \mathrm{~mm}$, the applied load, $P$, is defined as the design value of lateral bearing capacity of single piles. As a result, the $m$ value used to determine the lateral bearing capacity of single piles can be obtained from the $m-Y_{0}$ curve.

Figure 7 shows the deduced $m$ - $Y_{0}$ curves for single PC piles with and without improved soil surrounds based on 


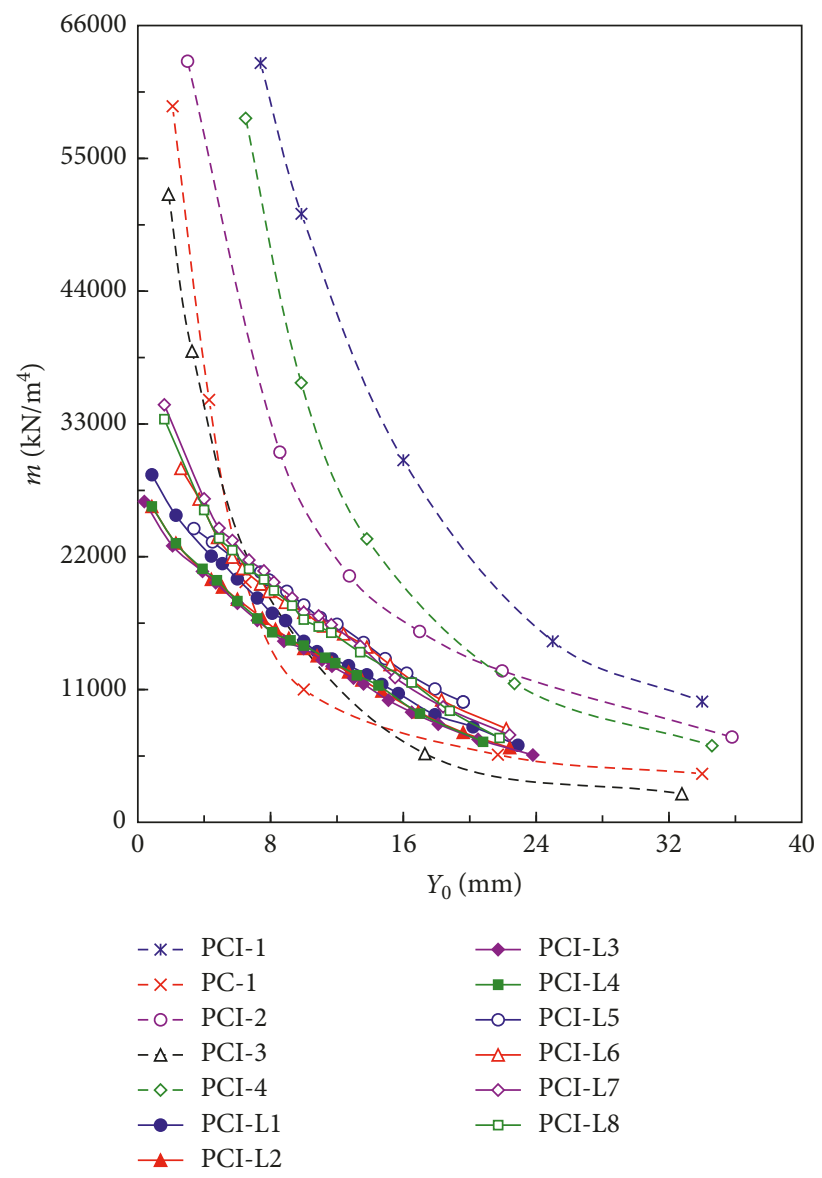

Figure 7: Deduced $m-Y_{0}$ curves for lateral test piles.

TABLE 4: Detailed information of test piles (PCI-2 PCI-4; PCI-L1 PCI-L8).

\begin{tabular}{|c|c|c|c|c|c|c|}
\hline \multirow{2}{*}{$\begin{array}{l}\text { Pile } \\
\text { identifier }\end{array}$} & \multirow{2}{*}{$\begin{array}{c}\text { Concrete } \\
\text { grade }\end{array}$} & \multicolumn{3}{|c|}{ PC piles } & \multicolumn{2}{|c|}{ Improved soil surrounds } \\
\hline & & Outer diameter/edge length $(\mathrm{mm})$ & Wall thickness (mm) & Length $(\mathrm{m})$ & Outer diameter $(\mathrm{mm})$ & Length $(\mathrm{m})$ \\
\hline PCI-2 & $\mathrm{C} 80$ & 400 & 95 & 12 & 800 & 15 \\
\hline PCI-3 & $\mathrm{C} 80$ & 600 & 110 & 9 & 800 & 9 \\
\hline PCI-4 & $\mathrm{C} 80$ & 600 & 110 & 9 & 800 & 9 \\
\hline PCI-L1, L2* & C35 & 220 & - & 6 & 600 & 7 \\
\hline PCI-L3, L4* & C35 & 220 & - & 4 & 600 & 7 \\
\hline PCI-L5, L6* & $\mathrm{C} 35$ & 180 & - & 6 & 600 & 7 \\
\hline PCI-L7, L8* & C35 & 180 & - & 4 & 600 & 7 \\
\hline
\end{tabular}

*Note. PCI-L1 PCI-L8 are solid square PC piles with improved soil surrounds reported by Jamsawang et al. [4].

the results of pile load tests, which were conducted in Nantong, China, and reported by Jamsawang et al. [4]. The detailed information of such test piles is summarized in Tables 1 and 4. Generally, under large deflection levels, the $m$ value gradually decreased with the increasing deflection. At a pile-head deflection of $10 \mathrm{~mm}$, the backcalculated and recommended $m$ values (shown in Figure 7 and Table 3, resp.) are compared in Table 5. From these results, it is clearly demonstrated that the back-calculated $m$ value for the PC pile without improved soil surrounds was very close to the recommended $m$ value. However, the back-calculated $m$ values for PC piles with improved soil surrounds were 1.6 to 5.0 times larger than the recommended values for PC piles alone in soil. This denotes that the improved soil surrounds led to an obvious increase in the $m$ values of the PC piles.

3.3. Modified Coefficient. In order to clearly distinguish the significant difference between the back-calculated and recommended $m$ values, a modified coefficient, $\xi_{\mathrm{m}}$, is defined as follows:

$$
\xi_{\mathrm{m}}=\frac{\text { the back }- \text { calculated } m \text { value }}{\text { the recommended } m \text { value (maximum) }} .
$$

Table 6 shows the modified coefficients for different test piles and several parameters of outer improved soil surrounds. It can be seen from Table 6 that the strength of 
TABLE 5: Back-calculated and recommended $m$ values at a pile-head deflection of $10 \mathrm{~mm}$.

\begin{tabular}{|c|c|c|c|}
\hline Pile identifier & Type of foundation soil & Back-calculated $m$ value $\left(\mathrm{kN} / \mathrm{m}^{4}\right)$ & Recommended $m$ value $\left(\mathrm{kN} / \mathrm{m}^{4}\right)$ \\
\hline $\begin{array}{l}\text { PCI-1 } \\
\text { PC-1 }\end{array}$ & Silty clay, silty sand & $\begin{array}{l}50000 \\
11000\end{array}$ & $\begin{array}{l}6000 \sim 10000 \\
6000 \sim 10000\end{array}$ \\
\hline $\begin{array}{l}\text { PCI-2 } \\
\text { PCI-3 } \\
\text { PCI-4 } \\
\end{array}$ & Silty soil, silty sand & $\begin{array}{l}25000 \\
16000 \\
35000 \\
\end{array}$ & $\begin{array}{l}6000 \sim 10000 \\
6000 \sim 10000 \\
6000 \sim 10000 \\
\end{array}$ \\
\hline $\begin{array}{l}\text { PCI-L1 } \\
\text { PCI-L2 } \\
\text { PCI-L3 } \\
\text { PCI-L4 } \\
\text { PCI-L5 } \\
\text { PCI-L6 } \\
\text { PCI-L7 } \\
\text { PCI-L8 }\end{array}$ & 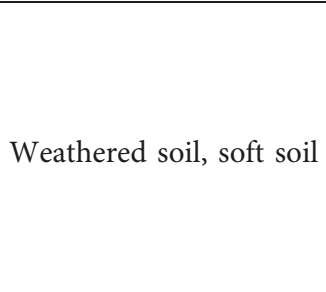 & $\begin{array}{l}15000 \\
14400 \\
14400 \\
14400 \\
18000 \\
17400 \\
17400 \\
16800\end{array}$ & $\begin{array}{l}4500 \sim 6000 \\
4500 \sim 6000 \\
4500 \sim 6000 \\
4500 \sim 6000 \\
4500 \sim 6000 \\
4500 \sim 6000 \\
4500 \sim 6000 \\
4500 \sim 6000\end{array}$ \\
\hline
\end{tabular}

Table 6: Modified coefficients for different test piles and several parameters of outer improved soil surrounds.

\begin{tabular}{|c|c|c|c|c|}
\hline \multirow{2}{*}{ Pile identifier } & \multicolumn{3}{|c|}{ Improved soil surrounds } & \multirow{2}{*}{ Modified coefficient $\xi_{\mathrm{m}}$} \\
\hline & Cross-sectional area $\left(\mathrm{m}^{2}\right)$ & Compressive strength $(\mathrm{MPa})$ & Compressive bearing capacity $(\mathrm{kN})$ & \\
\hline PCI-1 & 0.3768 & 2.00 & 753.6 (dry spraying) & 5.0 \\
\hline PCI-2 & 0.3768 & 0.77 & 290.1 (wet spraying) & 2.5 \\
\hline PCI-3 & 0.2198 & 0.60 & 131.9 (wet spraying) & 1.6 \\
\hline PCI-4 & 0.4067 & 1.20 & 488.0 (dry-wet spraying) & 3.5 \\
\hline PCI-L1 & 0.2342 & 0.94 & 219.5 (wet spraying) & 2.5 \\
\hline PCI-L2 & 0.2342 & 0.91 & 212.7 (wet spraying) & 2.4 \\
\hline PCI-L3 & 0.2342 & 0.88 & 205.8 (wet spraying) & 2.4 \\
\hline PCI-L4 & 0.2342 & 0.88 & 205.8 (wet spraying) & 2.4 \\
\hline PCI-L5 & 0.2502 & 0.93 & 233.6 (wet spraying) & 3.0 \\
\hline PCI-L6 & 0.2502 & 0.90 & 225.3 (wet spraying) & 2.9 \\
\hline PCI-L7 & 0.2502 & 0.90 & 225.3 (wet spraying) & 2.9 \\
\hline PCI-L8 & 0.2502 & 0.87 & 217.0 (wet spraying) & 2.8 \\
\hline
\end{tabular}

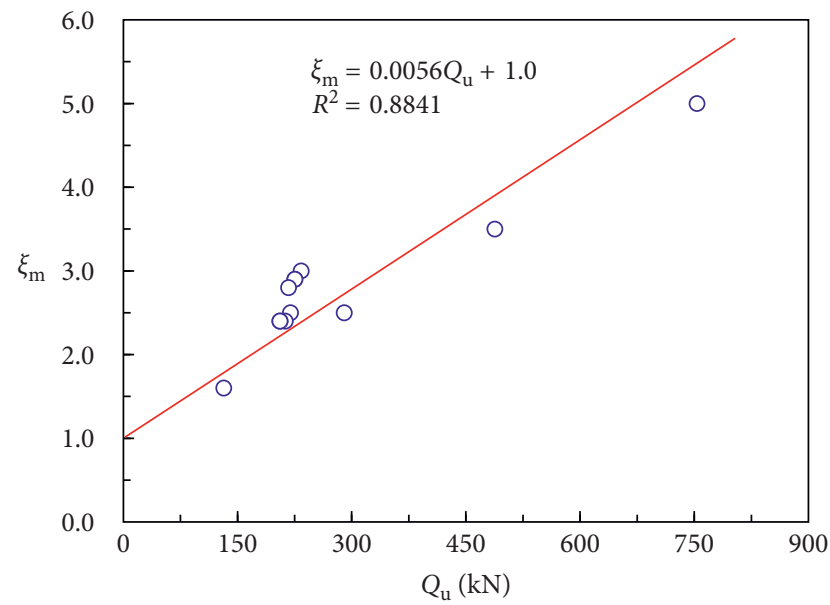

Figure 8: Correlation between the modified coefficient and compressive bearing capacity of improved soil surrounds.

cement-treated soil with the wet spraying method was generally lower than that with the dry spraying method. It is known that the improvement of the soil with cement treatment is referred to as the chemical reactions between cement and the soil particles, and the water-cement ratio has an important influence on the mechanical properties of cement-treated soil. Once the water-cement ratio exceeds the optimum level, the strength of cement-treated soil obviously decreases with the increasing water-cement ratio $[27,28]$. It is worth noting that, in practical engineering, the initial water content of the natural clay undoubtedly increases the water-cement ratio of the cement-treated soil. Thus, it can be concluded that the lower strength of a DCM column can always occur when constructed using the wet spraying method, especially in coastal areas with a high groundwater level and water content.

It can be observed that the $m$ value for PC piles with improved soil surrounds was not only dependent on soil properties but also closely related to the compressive strength and cross-sectional area of outer improved soil surrounds. The larger the cross-sectional area and the higher the compressive strength of the improved soil surrounds, the larger the modified coefficient. This can be attributed to the different reinforcement effects of outer improved soil surrounds. Fortunately, the reinforcement effect of outer improved soil surrounds was found to be positively related to its compressive bearing capacity (denoted as $Q_{u}(\mathrm{kN})$ ). Thus, a correlation relationship between $\xi_{\mathrm{m}}$ and $Q_{u}$ can be established. As shown in Figure 8, for PC piles with improved soil surrounds, $\xi_{\mathrm{m}}$ exhibited an 


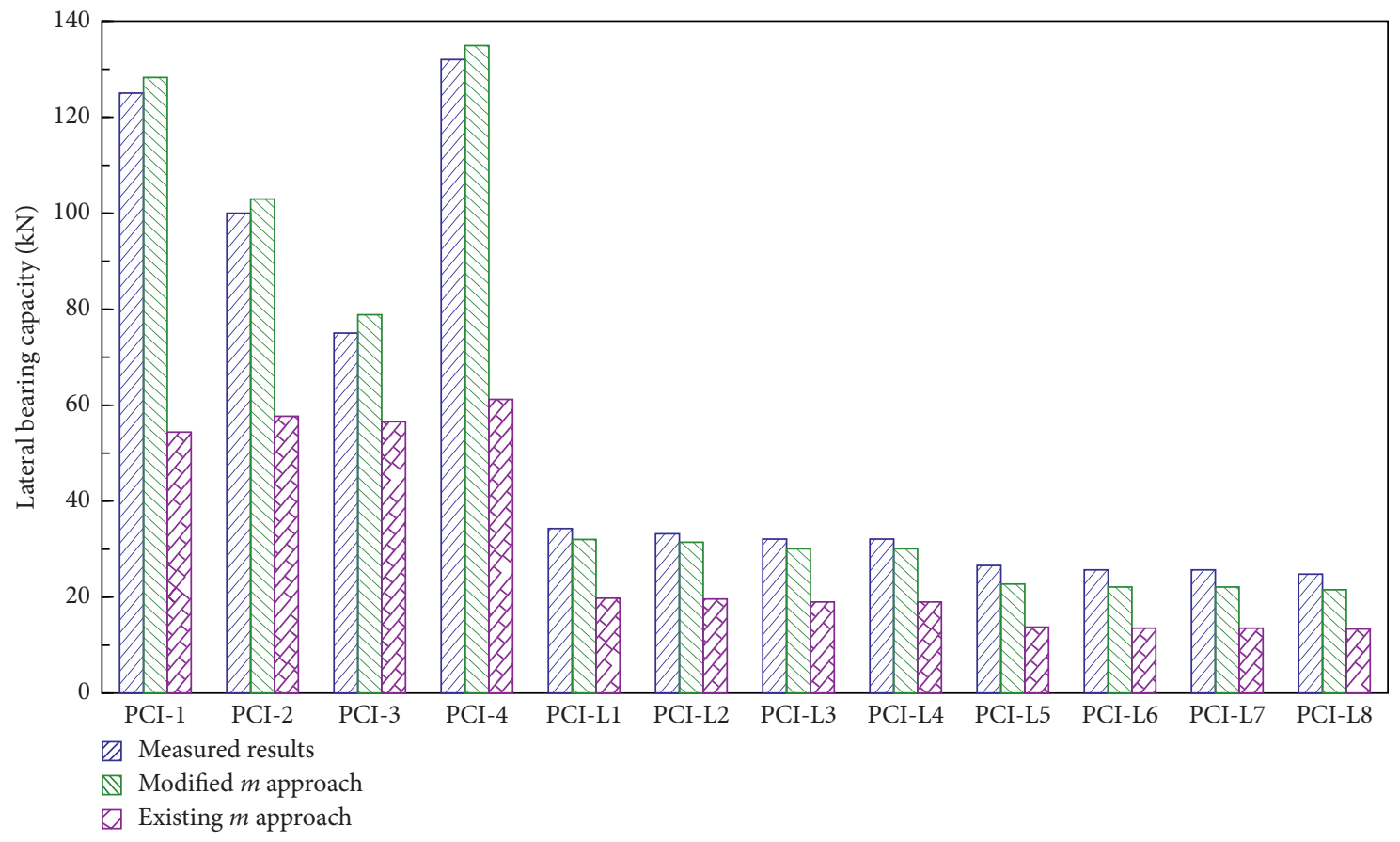

FIgURE 9: Comparison of lateral bearing capacity using the modified and existing $m$ approach and measured results.

approximately linear increase with $Q_{u}$. Moreover, when $Q_{u}=0$ (corresponding to the PC pile without improved soil surrounds), the modified coefficient, $\xi_{\mathrm{m}}$, should be determined as 1.0. Thus, the linear correlation function is fitted as follows:

$$
\xi_{\mathrm{m}}=0.0056 \mathrm{Q}_{\mathrm{u}}+1 .
$$

In summary, for laterally loaded single PC piles with improved soil surrounds, the $m$ value can be obtained by introducing the modified coefficient. Thus, a modified $m$ approach is proposed by modifying the $m$ value based on the existing $m$ approach, that is, by substituting the modified $m$ value into the existing equation. The proposed $m$ approach can account for the cement-treated soil reinforcement.

\section{Evaluation of the Modified and Existing $m$ Approach for Piles with Improved Soil Surrounds}

According to the pile load test data presented in this study, the lateral bearing capacities of these test piles were calculated using the modified and existing $m$ approach, as shown in Figure 9. It is clearly seen that the lateral bearing capacities obtained by the modified $m$ approach were all in good agreement with the measured results, with a relative error range of $15 \%$. These results also indicate that the modified $m$ approach was able to effectively account for the reinforcement effect of outer improved soil surrounds. Therefore, it is feasible and appropriate to predict the lateral bearing capacity of PC piles with improved soil surrounds by using the modified $m$ approach. However, the calculated bearing capacities from the existing $m$ approach were obviously smaller than that measured, indicating that the existing $m$ approach would significantly underestimate the lateral capacity of such reinforced piles. This implies that designs of laterally loaded single PC piles with improved soil surrounds using the existing $m$ approach would tend to be conservative.

To further assess the suitability of the modified $m$ approach for the analysis of laterally loaded piles with improved soil surrounds, the deflection and moment responses derived using the modified and existing $m$ approach were compared with the numerical results (from Figures 5 and 6), as demonstrated in Figures 10 and 11, respectively. It is evident that both the pile deflection and moment from the existing $m$ approach were significantly larger than those from the numerical results. However, compared with the numerical results, the modified $m$ approach can accurately predict the lateral response of a reinforced PC pile. This also further indicates that the proposed $m$ approach is applicable for laterally loaded single PC piles with improved soil surrounds and would be especially useful in practice.

\section{Conclusions}

In this paper, the numerical and theoretical investigation on the lateral bearing capacity of a single PC pile with improved soil surrounds was presented. The existing $m$ approach (recommended by Technical Code for Building Pile Foundations (JGJ 94-2008)) was modified by taking into account the reinforcement effect of outer improved soil surrounds. The primary conclusions that can be obtained from this study are summarized below:

(1) By applying cement-improved soil around a PC pile, the lateral deflection and the maximum bending moment of the PC pile are significantly reduced. 


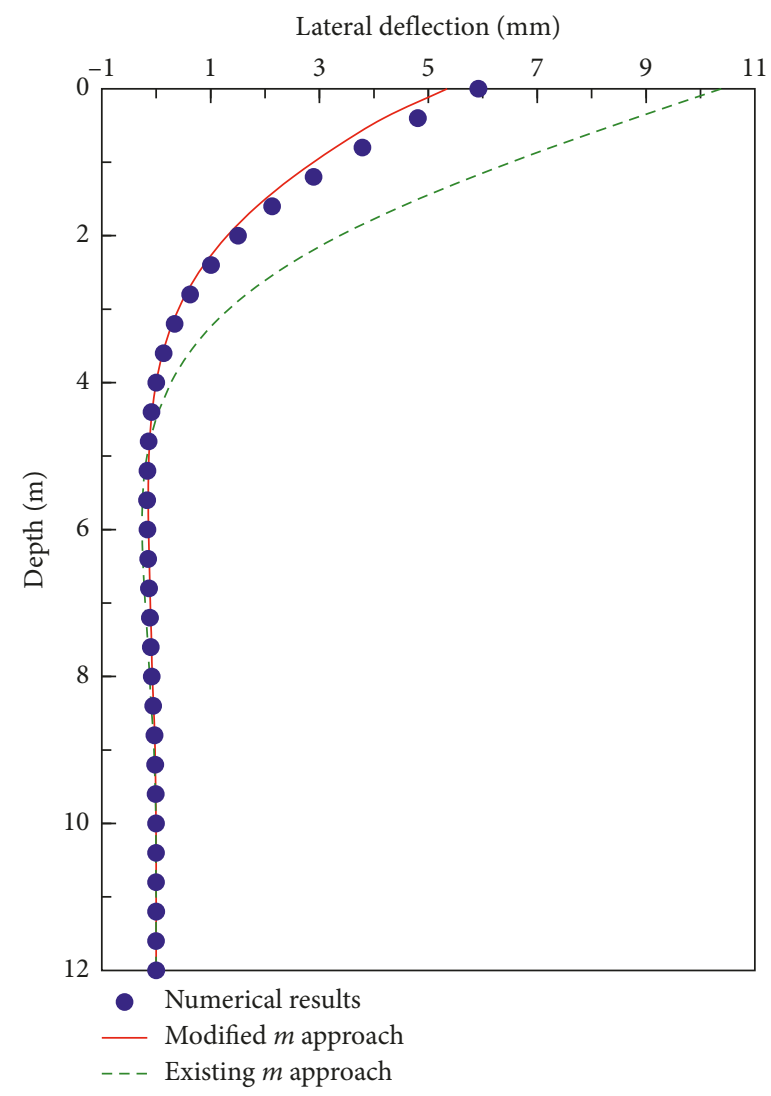

FIGURE 10: Comparison of predicted pile deflections from the modified and existing $m$ approach and numerical results at a lateral load of $100 \mathrm{kN}$.

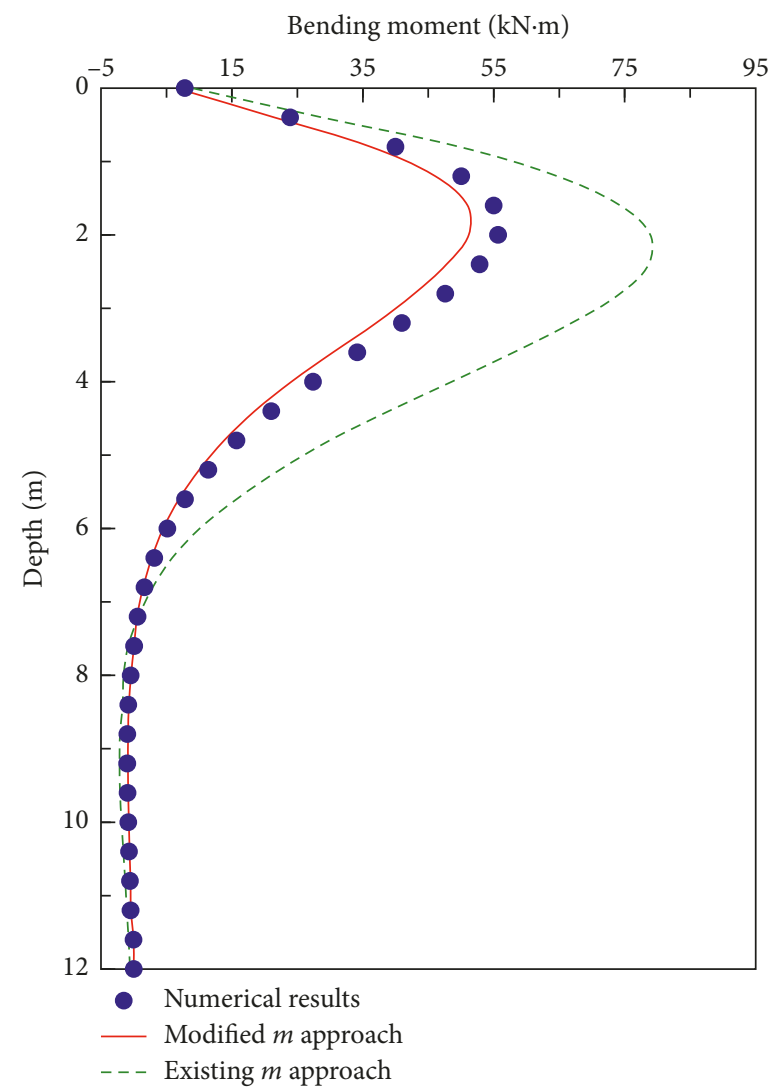

FIGURE 11: Comparison of predicted pile moments from the modified and existing $m$ approach and numerical results at a lateral load of $100 \mathrm{kN}$. 
Nevertheless, the lateral performance of the PC pile with improved soil surrounds is similar to that of the PC pile alone in soil. Thus, the lateral bearing capacity of a single PC pile with improved soil surrounds can still be calculated using the $m$ approach.

(2) To account for the reinforcement effect of improved soil surrounds on the laterally loaded single PC piles, a modified $m$ approach was proposed by introducing a modified coefficient based on the existing $m$ value. The modified coefficient, $\xi_{\mathrm{m}}$, is approximately linearly related to the compressive bearing capacity of cement-improved soil surrounds.

(3) Compared with numerical results, the proposed $m$ approach can accurately predict the lateral bearing capacity of single PC piles with improved soil surrounds. In addition, the existing $m$ approach obviously underestimates the lateral bearing capacity of such reinforced PC piles, thus leading to a conservative prediction of their lateral performance.

\section{Data Availability}

The data used to support the findings of this study are available from the corresponding author upon request.

\section{Conflicts of Interest}

The authors declare that they have no conflicts of interest.

\section{Acknowledgments}

This study was supported by the National Key R\&D Program of China (Grant no. 2016YFC0800200) and the National Natural Science Foundation of China (Grant no. 41372308).

\section{References}

[1] P. Dong, R. Qin, and Z. Chen, "Bearing capacity and settlement of concrete-cored DCM pile in soft ground," Geotechnical and Geological Engineering, vol. 22, no. 1, pp. 105-119, 2004.

[2] X. N. Gao, S. Liu, and P. Dong, "Application of concrete-cored DCM pile in soft ground treatment of highway bridgehead," in Proceedings of the Fourth International Conference on Grouting and Deep Mixing, New Orleans, LA, USA, February 2012.

[3] V. P. Faro, N. C. Consoli, F. Schnaid, A. Thomé, and L. da Silva Lopes, "Field tests on laterally loaded rigid piles in cement treated soils," Journal of Geotechnical and Geoenvironmental Engineering, vol. 141, no. 6, article 06015003 , 2015.

[4] P. Jamsawang, D. T. Bergado, and P. Voottipruex, "Field behaviour of stiffened deep cement mixing piles," Proceedings of the Institution of Civil Engineers-Ground Improvement, vol. 164, no. 1, pp. 33-49, 2011.

[5] A. Wonglert and P. Jongpradist, "Impact of reinforced core on performance and failure behavior of stiffened deep cement mixing piles," Computers and Geotechnics, vol. 69, pp. 93-104, 2015.

[6] P. Voottipruex, T. Suksawat, D. T. Bergado, and P. Jamsawang, "Numerical simulations and parametric study of SDCM and DCM piles under full scale axial and lateral loads," Computers and Geotechnics, vol. 38, no. 3, pp. 318-329, 2011.

[7] J. J. Zhou, X. N. Gong, K. H. Wang, R. H. Zhang, and T. L. Yan, "A model test on the behavior of a static drill rooted nodular pile under compression," Marine Georesources and Geotechnology, vol. 34, no. 3, pp. 293-301, 2016.

[8] J. J. Zhou, X. N. Gong, K. H. Wang, R. H. Zhang, and J. J. Yan, "Testing and modeling the behavior of pre-bored grouting planted piles under compression and tension," Acta Geotechnica, vol. 12, no. 5, pp. 1061-1075, 2017.

[9] S. Thiyyakkandi, M. Mcvay, M. P. Lai, and M. R. Herrera, "Suitability of jetted and grouted precast pile for supporting mast arm structures," Canadian Geotechnical Journal, vol. 54, no. 9, pp. 1231-1244, 2017.

[10] B. P. Liu, "Experimental study on the reinforced mixing pile respectively subjected to a vertical load or a lateral load," M.S. thesis, School of Civil Engineering, Tianjin University, Tianjin, China, 2006, in Chinese.

[11] K. M. Rollins, M. E. Adsero, and A. B. Dan, "Jet grouting to increase lateral resistance of pile group in soft clay," in Proceedings of the International Foundation Congress and Equipment Expo, pp. 265-272, Orlando, FL, USA, March 2009.

[12] C. Lin, J. Han, S. L. Shen, and Z. S. Hong, "Numerical modeling of laterally loaded pile groups in soft clay improved by jet-grouting," in Proceedings of the Fourth International Conference on Grouting and Deep Mixing, pp. 15-18, New Orleans, LA, USA, February 2012.

[13] L. Wang, B. He, Y. Hong, Z. Guo, and L. Li, "Field tests of the lateral monotonic and cyclic performance of jet-groutingreinforced cast-in-place piles," Journal of Geotechnical and Geoenvironmental Engineering, vol. 141, no. 5, article 06015001, 2015.

[14] B. He, L. Z. Wang, and Y. Hong, "Field testing of one-way and two-way cyclic lateral responses of single and jet-grouting reinforced piles in soft clay," Acta Geotechnica, vol. 12, no. 5, pp. 1021-1034, 2017.

[15] Z. Yang and B. Jeremić, "Numerical analysis of pile behaviour under lateral loads in layered elastic-plastic soils," International Journal for Numerical and Analytical Methods in Geomechanics, vol. 26, no. 14, pp. 1385-1406, 2002.

[16] Y. Kim and S. Jeong, "Analysis of soil resistance on laterally loaded piles based on 3D soil-pile interaction," Computers and Geotechnics, vol. 38, no. 2, pp. 248-257, 2011.

[17] L. F. Miao, A. T. C. Goh, K. S. Wong, and C. I. Teh, "Threedimensional finite element analyses of passive pile behaviour," International Journal for Numerical \& Analytical Methods in Geomechanics, vol. 30, no. 7, pp. 599-613, 2010.

[18] K. Georgiadis, S. W. Sloan, and A. V. Lyamin, "Undrained limiting lateral soil pressure on a row of piles," Computers and Geotechnics, vol. 54, no. 10, pp. 175-184, 2013.

[19] Z. H. Zhao, D. Y. Li, F. Zhang, and Y. Qiu, "Ultimate lateral bearing capacity of tetrapod jacket foundation in clay," Computers and Geotechnics, vol. 84, pp. 164-173, 2017.

[20] B. He, L.Z. Wang, and Y. Hong, "Capacity and failure mechanism of laterally loaded jet-grouting reinforced piles: field and numerical investigation," Science China Technological Sciences, vol. 59, no. 5, pp. 763-776, 2016.

[21] P. Jamsawang, N. Yoobanpot, N. Thanasisathit, P. Voottipruex, and P. Jongpradist, "Three-dimensional numerical analysis of a DCM column-supported highway embankment," Computers and Geotechnics, vol. 72, pp. 42-56, 2016. 
[22] A. Tyagi, M. F. B. Zulkefli, Y. Pan, S. H. Goh, and F. H. Lee, "Failure modes of tunnels with improved soil surrounds," Journal of Geotechnical and Geoenvironmental Engineering, vol. 143, no. 11, article 04017088, 2017.

[23] P. Jamsawang, P. Voottipruex, P. Boathong, W. Mairaing, and S. Horpibulsuk, "Three-dimensional numerical investigation on lateral movement and factor of safety of slopes stabilized with deep cement mixing column rows," Engineering Geology, vol. 188, pp. 159-167, 2015.

[24] L. J. Zhu, Y. M. Cheng, and D. B. Yang, "The analysis of instrumented piles under lateral load," Geomechanics \& Geoengineering, vol. 7, no. 1, pp. 27-37, 2012.

[25] JGJ 94-2008, Technical Code for Building Pile Foundations, China Architecture and Building Press, Beijing, China, 2008, in Chinese.

[26] X. M. Lou, H. Wu, and J. F. Huang, "Determination of slope coefficient of subgrade reaction of saturated clay based on $p-y$ curve," Chinese Journal of Geotechnical Engineering, vol. 34, no. 12, pp. 2206-2212, 2012, in Chinese.

[27] F. H. Lee, Y. Lee, S. H. Chew, and K. Y. Yong, "Strength and modulus of marine clay-cement mixes," Journal of Geotechnical and Geoenvironmental Engineering, vol. 131, no. 2, pp. 178-186, 2005.

[28] T. Tsuchida and Y. X. Tang, "Estimation of compressive strength of cement-treated marine clays with different initial water contents," Soils and Foundations, vol. 55, no. 2, pp. 359-374, 2015. 


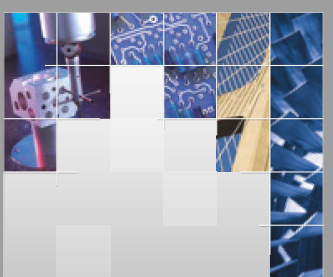

\section{Enfincering}
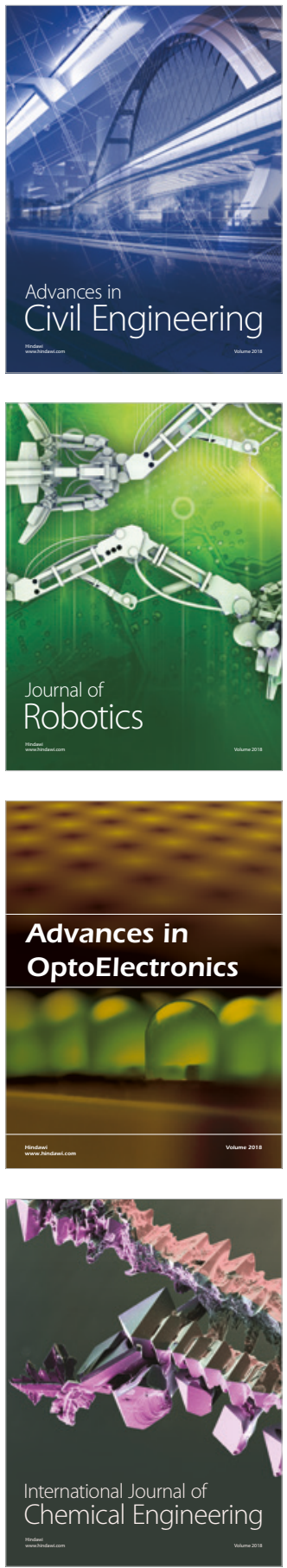

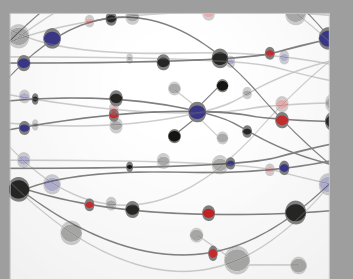

\section{Rotating \\ Machinery}

The Scientific World Journal

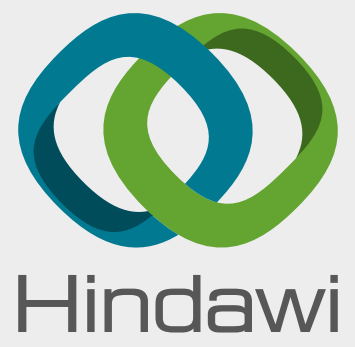

Submit your manuscripts at

www.hindawi.com
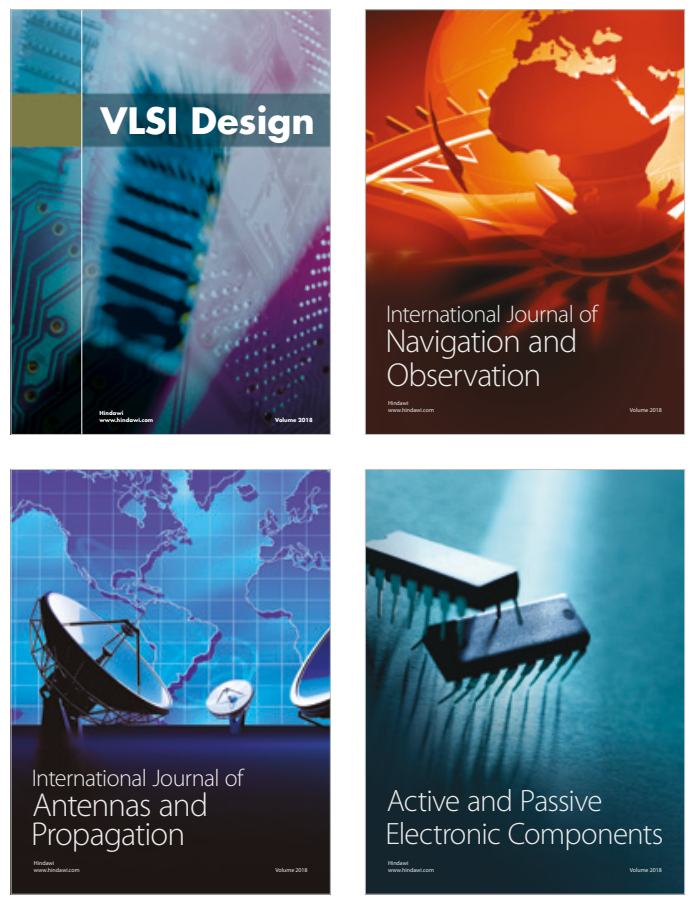
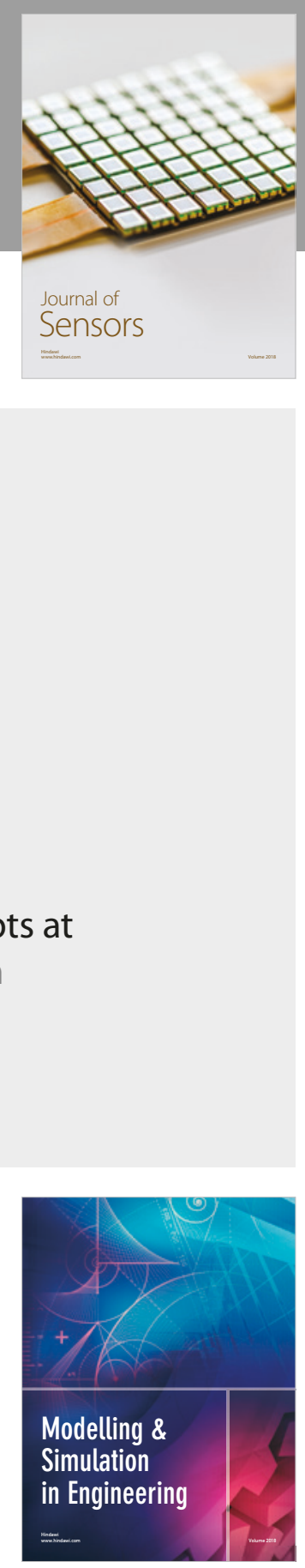

\section{Advances \\ Multimedia}
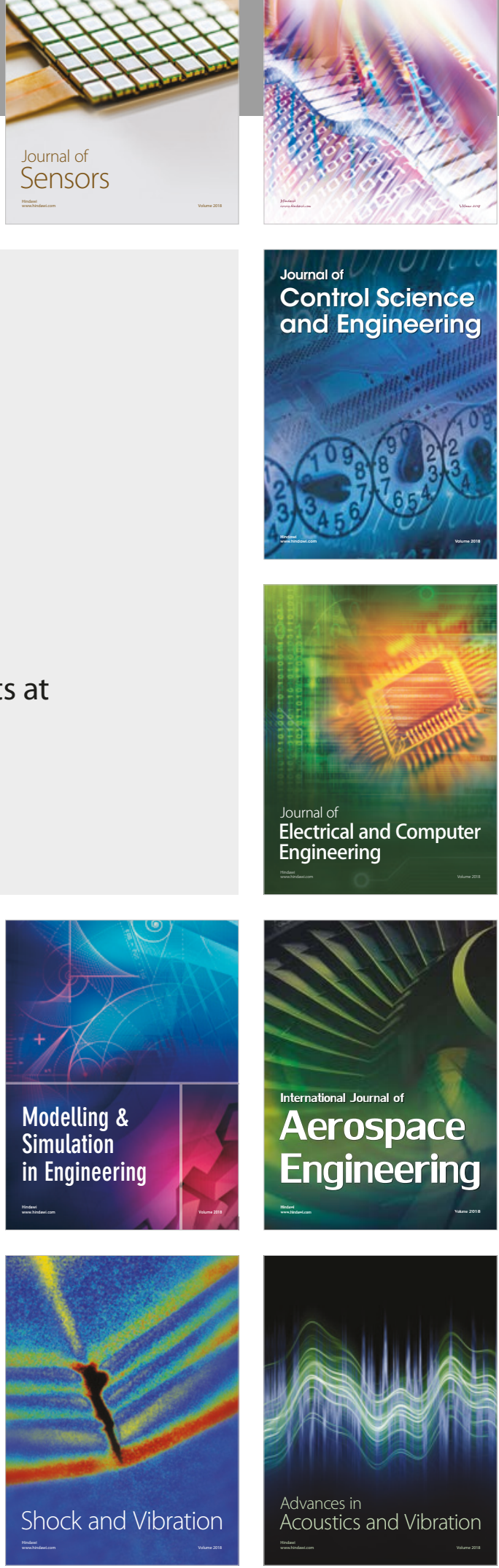